\title{
THE ASSOCIATION BETWEEN PARTICIPATION IN ORGANISED PHYSICAL ACTIVITY AND LEVEL OF PHYSICAL ACTIVITY AND INACTIVITY IN ADOLESCENT GIRLS
}

\author{
Karel Frömel, Jana Pelclová, Krzysztof Skalik*, Petra Nováková Lokvencová, Josef Mitáš
}

\author{
Faculty of Physical Culture, Palacký University, Olomouc, Czech Republic \\ * Academy of Physical Education, Katowice, Poland
}

Submitted in December, 2011

BACKGROUND: An increase of leisure time and vigorous physical activity (PA) in girls can be supported by their regular participation in organised PA, as it brings numerous health benefits and is an important part of healthy lifestyle.

OBJECTIVE: This study aimed to examine whether there are differences in physical activity and inactivity structure and levels in girls who do not participate in any organised PA and girls who regularly participate in physical education or training classes.

METHODS: The sample comprised 497 girls (age $17.94 \pm 0.52$ years) from Poland participating never (group 1), or once (group 2), twice (group 3), and three or four times (group 4) a week in any organised PA. The Polish version of the International Physical Activity Questionnaire (IPAQ), accelerometer ActiGraph GT1M and activity and inactivity logs were used to assess the level and structure of physical activity and inactivity.

RESULTS: Girls participating in organised PA three or more times a week showed significantly the highest values of steps/day, moderate and vigorous PA, and leisure time PA, but also inactivity in comparison to girls without participation in organised PA.

CONCLUSIONS: This study provides the evidence supporting the positive link between a number/week participation in organised PA and PA level. However, the findings from this study also advocate the need of increasing PA and reducing inactivity in girls in school or after-school periods, regardless of the participation in organised PA.

Keywords: Steps/day, moderate and vigorous physical activity, accelerometer, IPAQ, physical education lesson.

\section{BACKGROUND}

The health benefits of regular physical activity (PA) in youth include the prevention of many risk factors (obesity, high levels of body fat and cholesterol, hypertension) that could set up themselves throughout childhood and project into adulthood (Steinberger \& Daniels, 2003; Sung et al., 2006). However, PA drops exponentially during the adolescent period (Allison, Adlaf, Dwyer, Lysy, \& Irving, 2007) and many adolescents place their health at risk due to insufficient PA (Lowry, Galuska, Fulton, Wechsler, \& Kann, 2002). Most studies show that girls are less physically active than boys (Gavarry, Giacomoni, Bernard, Seymat, \& Falgairette, 2003; Norman et al., 2006; Pearson, Atkin, Biddle, Gorely, \& Edwardson, 2009; Sanchez et al., 2007) and at the age of 9-12 show less moderate to vigorous physical activity (MVPA) than boys (Kahn et al., 2008). Furthermore, concerning the daily structure of PA in young adolescents (Loucaides \& Jago, 2008), it is apparent that girls show significantly lower total daily PA than boys before school, at school, in a $20 \mathrm{~min}$. recess and after school. Majority of adolescent females do not meet health recommendations for physical activity and generally are a population group at risk as far as inactive lifestyle is concerned (Butcher, Sallis, Mayer, \& Woodruff, 2008). Lower level of PA in girls is primarily due to lower PA in leisure time (Flohr et al., 2006; Frömel et al., 2007; Tudor-Locke et al., 2006), lower PA at weekends (Duncan, Duncan, \& Schofield, 2008; Groffik, Frömel, \& Pelclová, 2008) and less vigorous PA in total weekly PA (Amstrong \& Welsman, 2006; Frömel et al., 2007).

An increase of leisure time and vigorous PA in girls can be supported by their regular participation in organised PA, as it brings numerous health benefits (Pangrazi, 2000) and is an important part of healthy lifestyle; and school has an essential role in it (Park \& Kim, 2008; Trost \& Loprinzi, 2008). The possibility to participate in regular organised PA is within either physical education (PE) classes during school hours or within after-school programmes. Due to the regular participation in PE classes at school children and youth might increase their overall daily PA (Fairclough \& Stratton, 2005a; 2005b), whether it is the number of steps a day (Jago, Baranowski, Zakeri, \& Harris, 2005; Morgan, Beighle, \& Pangrazi, 2007; Mota et al., 2008; Peiró-Velert, Devís-Devís, Beltrán-Carrillo, \& Fox, 2008; Tudor-Locke et al., 2006) or moderate to vigorous PA (Gordon-Larsen, McMurray, \& Popkin, 2000; Morgan 
et al., 2007; Mota et al., 2008; Myers, Strikmiller, Webber, \& Berenson, 1996). Moreover, PA programmes within after-school period have greater potential for improving physical activity levels and other health-related aspects and are emerging as potentially useful and feasible for PA promotion (Beets, Beighle, Erwin, \& Huberty, 2009).

Nevertheless, studies have examined the effect of the participation in organised PA using either subjective or objective methods of assessment. E.g. Flohr et al. (2006) evaluated the pedometer-assessed PA patterns in children and differences between participants in afterschool organised PA and non-participants; using a questionnaire, Santos et al. (2009) assessed the relationship between participation in organized and non-organized PA, commuting to school and BMI; and Fairclough and Stratton (2005b) used heart rate telemetry to assess PA levels during high school PE classes. The authors are not aware of any research that investigated the frequency of the participation in organised PA using the combination of subjective and objective methods e.g. questionnaire, accelerometers and daily PA and physical inactivity selfrecord logs, thus allowing the examination of its effects in a more comprehensive way.

Therefore, the aim of the study was to examine, using objective and subjective methods, whether there are differences in PA and physical inactivity (PI) structure and levels in girls who do not participate in any organised PA and girls who regularly participate in PE or training classes once, twice or three or more times a week.

\section{METHODS}

\section{Participants}

Monitoring of weekly PA was carried out at 15 randomly selected secondary schools with approximately equal material background (sports equipment) for PE and extracurricular PA and in 2 randomly selected classes at each school in Katowice region in Poland in spring (April-May) and in fall (September-October) seasons having the same mean temperatures of $\approx 10^{\circ} \mathrm{C}$ (according to measurements taken four times within 24 hour periods), avoiding warm summers and cold winters. A consent from both parents and the girls was required prior the onset of the monitoring. Out of the pupils approached, 29 girls refused to participate. Moreover, we excluded data of 103 participants due to technical causes (e.g. when the accelerometer had been left lying for some time within one week monitoring); and 15 participants due to incorrect completing of the questionnaire. In total, our sample comprised 497 girls (age $17.94 \pm 0.52$ years) participating never (group 1), once (group 2), twice (group 3), or three or four times (group 4) a week in any organised PA. Organised PA included PE classes at school and any other lessons of exercise and training under the supervision of a teacher or coach. In Poland, there are recommended three classes of PE a week in the curriculum. The groups' characteristics are showed in TABLE 1.

\section{Measures and procedure}

In order to obtain the most accurate and complex information about the effect which the frequency of weekly participation might have on physical activity, the combination of subjective and objective methods was used:

- To measure the subjective assessment of weekly PA, the Polish version of the International Physical Activity Questionnaire (IPAQ) - long was used. The questionnaire was applied one day prior to weekly monitoring by accelerometer which allows us to eliminate the possible reactivity of accelerometer. The girls completed the questionnaires upon instructions provided by a qualified researcher. The validity and reliability of the IPAQ questionnaire (www.ipaq. ki.se) are proved by previous studies (Cerin, Saelens, Sallis, \& Frank, 2006; Craig et al., 2003). Forward and back-translation were applied in the standardization of the Polish version of the questionnaire in compliance with the "Guide to Cultural Adaptation and Translation of the IPAQ Instruments" (http:// www.ipenproject.org/surveytrans.htm). The results of the questionnaire were processing in agreement

TABLE 1

The sample characteristics according to frequency of organised PA participation $(\mathrm{N}=497)$

\begin{tabular}{|l|c|c|c|c|c|c|c|c|}
\hline \multirow{2}{*}{ Characteristics } & \multicolumn{2}{|c|}{$\begin{array}{c}\text { Group 1 } \\
(\mathrm{n}=142)\end{array}$} & \multicolumn{2}{c|}{$\begin{array}{c}\text { Group 2 } \\
(\mathrm{n}=144)\end{array}$} & \multicolumn{2}{c|}{$\begin{array}{c}\text { Group 3 } \\
(\mathrm{n}=113)\end{array}$} & \multicolumn{2}{c|}{$\begin{array}{c}\text { Group 4 } \\
(\mathrm{n}=98)\end{array}$} \\
\cline { 2 - 10 } & $M$ & $S D$ & $M$ & $S D$ & $M$ & $S D$ & $M$ & $S D$ \\
\hline Age (years) & 17.95 & 0.50 & 18.03 & 0.50 & 17.97 & 0.51 & 17.77 & 0.54 \\
\hline Height (cm) & 166.54 & 5.96 & 166.92 & 6.05 & 166.16 & 6.62 & 166.31 & 7.13 \\
\hline Weight $(\mathbf{k g})$ & 57.42 & 8.26 & 58.41 & 9.03 & 57.22 & 7.02 & 57.46 & 7.86 \\
\hline BMI $\left(\mathbf{k g} \times \mathbf{~ m}^{-\mathbf{2}}\right)$ & 20.70 & 2.77 & 20.92 & 2.61 & 20.73 & 2.32 & 20.77 & 2.60 \\
\hline
\end{tabular}

Legend: M - mean, SD - standard deviation, BMI - body mass index 
with the "Guidelines for data processing and analysis of the international physical activity questionnaire" (www.ipaq.ki.se).

- Weekly PA monitoring was carried out also objectively using ActiGraph GT1M accelerometers (Manufacturing Technology Inc., FL, USA). According to Welk, Schaben and Morrow study (2004), the ActiGraph accelerometer appeared to have acceptable reliability for most research applications (generalizability values above 0.60 and ICC values above 0.80 ). Girls were instructed on how to affix the accelerometer by means of an elastic belt clipped at the mid-axillary line of the right hip. Moreover, they were asked to wear the accelerometer for at least 10 waking hours for consecutive seven days, with the exception of times used to perform water activities. Using manufacture supplied software, the time sampling interval of the accelerometers was set at 1 minute, and step mode was activated. After the seven day period, the recorded data containing activity counts and steps were downloaded with the assistance of the manufacturer's software. Downloaded counts data were analyzed according to scoring for younger adults established by Freedson, Melanson and Sirard (1998). In order to identify the boundary between light ( $<3$ METs) and moderate activity (3-6 METs), and moderate and vigorous activity (> 6 METs) the cut-off points of 1951 and 5724 counts/minute, respectively, were used.

- Daily PA and PI logs were used for subjects to selfrecord times when accelerometer was worn and activity and inactivity patterns so that we could obtain a more accurate picture of the individual's physical activity profile and were able to make some judgment while assessing the data (Esliger, Copeland, Barnes, \& Tremblay, 2005). Specifically, the girls recorded the times when they put on the device, arrived at school, started and finished PE class, departed from school, the beginning and end of any other organised PA, and taking off the device in the evening. Further, they were instructed to record the types and time of physical activities performed in at least 10 minutes bouts, e.g. walking, running, cycling, swimming, dancing, playing volleyball, basketball, etc. Moreover, types and time of inactivities were recorded (sitting-lying-standing) while watching TV, working with a computer, studying, etc. at school, attending cultural and sports events, and passive transport. Girls were instructed to record the data every evening after taking off the device. To assess the activity log, physical activities were assigned counts per minute equal to the MET value published in the Compendium of Physical Activities (Ainsworth et al., 2000).

\section{Statistical analyses}

The statistical packages Statistica 9 (StatSoft, 2009) and SPSS 18 (SPSS, Inc., Chicago, IL) were used for data analysis with significant levels set at $\mathrm{p}<0.05$. Data were normally distributed for all variables. Descriptive statistics were presented as means (M) and standard deviation (SD) in case of step-based data and as median $(\mathrm{Mdn})$ and inter-quartile ranges (IQR) in case of questionnaire and activity and inactivity logs and minutesbased accelerometer data. Kruskal-Wallis test was used to test whether there are differences among groups according to frequency of participation in organised PA, the intensity of PA, structure of PA (school, transportrelated, domestic and leisure-time domains) and PI (watching TV, working on PC, learning, sitting at school, culture events, passive transport). Mann-Whitney U-test was used to identify the differences between two groups. Repeated analysis of variance was used to test whether participation in organised PA is associated with steps/ day of the week. Schéffe post-hoc test was used to identify the differences between groups. Coefficients $\omega^{2}$ (Tolson, 1980), Cohen's $d$ (Cohen, 1988) and $\eta^{2}$ (Sheskin, 2007) were used as the indicators of effect size.

\section{RESULTS}

Characteristics of overall physical activity and physical activity in organised lessons

TABLE 2 shows the statistically significant differences among groups in daily physical activity (active energy expenditure, steps). There were not found any significant differences among groups 2-4 in intensity and volume of PE and training classes.

\section{Daily step values}

The girls participating in organised PA 3-4 times a week had significantly higher number of steps/day than girls who did not participate in any organised PA $(p=0.000, d=0.57)$. Regardless of the participation in organised PA, the mean values for weekdays were significantly higher than for weekends $(F=104.11$, $\left.\mathrm{p}=0.000, \omega^{2}=0.38\right)$ in all girls. TABLE 3 shows that girls who participated in organised PA 3-4 times a week had significantly higher number of steps/day than girls who did not participate at all on both weekdays and weekend days.

The girls participating 3-4 times a week in organised PA showed significantly higher number of daily steps than girls never participating in organised PA on Monday $\left(\mathrm{F}=7.75, \mathrm{p} \approx 0.000, \omega^{2}=0.039\right)$, Thursday $\left(\mathrm{F}=4,51, \mathrm{p}=0.004, \omega^{2}=0.021\right)$, Friday $(\mathrm{F}=5.14$, $\left.\mathrm{p}=0.002, \omega^{2}=0.024\right)$ and Saturday $(\mathrm{F}=2.91, \mathrm{p}=0.034$, $\left.\omega^{2}=0.011\right)$ (Fig. 1). The girls participating in organised 
TABLE 2

Characteristics of overall physical activity and physical activity in organised lessons according to frequency of organised PA participation $(\mathrm{N}=497)$

\begin{tabular}{|c|c|c|c|c|c|c|c|c|c|c|c|}
\hline & \multicolumn{2}{|c|}{$\begin{array}{l}\text { Group 1 } \\
(\mathrm{n}=142)\end{array}$} & \multicolumn{2}{|c|}{$\begin{array}{l}\text { Group 2 } \\
(\mathrm{n}=144)\end{array}$} & \multicolumn{2}{|c|}{$\begin{array}{l}\text { Group 3 } \\
(\mathrm{n}=113)\end{array}$} & \multicolumn{2}{|c|}{$\begin{array}{c}\text { Group } 4 \\
(\mathrm{n}=98)\end{array}$} & \multirow[t]{2}{*}{$\mathbf{F}$} & \multirow[t]{2}{*}{$\mathbf{p}$} & \multirow[t]{2}{*}{$\omega^{2}$} \\
\hline & $M$ & $S D$ & $M$ & $S D$ & $M$ & $S D$ & $M$ & $S D$ & & & \\
\hline $\operatorname{AEE}\left(k^{2 c a l} \times\right.$ day $\left.^{-1}\right)$ & 297.2 & 135.2 & 340.4 & 146.6 & 350.6 & 135 & 372.1 & 155.3 & $6.05^{\mathrm{a}, \mathrm{b}}$ & 0.000 & 0.03 \\
\hline Steps $\times$ day $^{-1}$ & 7,900 & 2,586 & 8,693 & 2,455 & 9,023 & 2,387 & 9,472 & 2,939 & $4.21^{\mathrm{a}}$ & 0.006 & 0.02 \\
\hline LPE $\left(\right.$ steps $\times$ hour $\left.^{-1}\right)$ & - & - & 1,351 & 1,154 & 1,378 & 913 & 1,266 & 934 & 0.34 & 0.714 & - \\
\hline LPE (METs) & - & - & 2.02 & 0.89 & 2.17 & 0.82 & 2.16 & 0.82 & 1.25 & 0.287 & - \\
\hline TL $\left(\right.$ steps $\times$ hour $\left.^{-1}\right)$ & - & - & 2,274 & 1,271 & 2,426 & 1,206 & 2,376 & 2,015 & 0.02 & 0.976 & - \\
\hline TL (METs) & - & - & 3.21 & 1.32 & 2.85 & 0.93 & 2.66 & 1.17 & 1.09 & 0.341 & - \\
\hline
\end{tabular}

Legend: M - mean, SD - standard deviation, LPE - physical education lessons, TL - training lessons, AEE - active energy expenditure, $\mathrm{a}$ - significant difference between groups (4-1), b - significant difference between groups (3-1), $\omega^{2}$ - coefficient of effect size

TABLE 3

Mean steps a day on the weekdays and weekend days in groups with different frequency of organised PA participation $(\mathrm{N}=497)$

\begin{tabular}{|c|c|c|c|c|c|c|c|c|c|c|c|}
\hline & \multicolumn{2}{|c|}{$\begin{array}{c}\text { Group 1 } \\
(\mathrm{n}=142)\end{array}$} & \multicolumn{2}{|c|}{$\begin{array}{c}\text { Group } 2 \\
(\mathrm{n}=144)\end{array}$} & \multicolumn{2}{|c|}{$\begin{array}{c}\text { Group } 3 \\
(\mathrm{n}=113)\end{array}$} & \multicolumn{2}{|c|}{$\begin{array}{l}\text { Group } 4 \\
(\mathrm{n}=98)\end{array}$} & \multirow[t]{2}{*}{$\mathbf{F}$} & \multirow[t]{2}{*}{$\mathbf{p}$} & \multirow[t]{2}{*}{$\omega^{2}$} \\
\hline & $M$ & $S D$ & $M$ & $S D$ & $M$ & $S D$ & $M$ & $S D$ & & & \\
\hline Weekdays & 8,295 & 2,693 & 9,170 & 2,571 & 9,539 & 2,537 & 9,872 & 2,791 & $8.21^{\mathrm{a}, \mathrm{b}}$ & 0.000 & 0.04 \\
\hline Weekend days & 6,911 & 3,278 & 7,501 & 3,490 & 7,735 & 3,518 & 8,472 & 4,803 & $3.47^{\mathrm{a}}$ & 0.02 & 0.02 \\
\hline
\end{tabular}

Legend: M - mean, SD - standard deviation, a - significant difference between groups (4-1), b - significant difference between groups (3-1), $\omega^{2}$ - coefficient of effect size

PA 2 times a week in comparison to girls who never participated showed significantly higher number of daily steps on Monday $(\mathrm{p}=0.037, \mathrm{~d}=0.365)$ and Wednesday $(p=0.005, d=0.428)$. There were found some significant differences in steps/day among groups on Tuesday $(F=1.56 ; p=0.197)$ and Sunday $(F=2.20, p=0.088)$.

Fig. 1 also shows significant variability in mean steps in each day of the week $\left(F=58.60, p=0.000, \omega^{2}=0.41\right)$ for the four groups of girls. The main differences were found between Sunday (the day with the lowest mean steps/day) and other days (Monday $\mathrm{p}=0.000, \mathrm{~d}=0.719$; Tuesday $\mathrm{p}=0.000, \mathrm{~d}=0.623$; Wednesday $\mathrm{p}=0.000$, $\mathrm{d}=0.771$; Thursday $\mathrm{p}=0.000, \mathrm{~d}=0.574$; Friday $\mathrm{p}=0.000, \mathrm{~d}=0.917$; Saturday $\mathrm{p}=0.000, \mathrm{~d}=0.592)$. On Friday, there were found higher mean values of steps/day when compared to Monday ( $p=0.007, d=0.223$ ), Tuesday $(\mathrm{p}=0.000, \mathrm{~d}=0.321)$, Thursday $(\mathrm{p}=0.000$, $\mathrm{d}=0.413)$ and Saturday $(\mathrm{p}=0.000, \mathrm{~d}=0.240)$.

\section{Intensity of PA}

The significant differences in low $(<3$ MET), moderate (3-5.9 MET) and vigorous ( $\geq 6$ MET) PA on school days among four groups are shown in TABLE 4. On weekend days, there were found significant differences among groups only in vigorous $\mathrm{PA}(\mathrm{H}=8.302$, $\mathrm{p}=0.040$ ); whereas the differences between groups were not significant in moderate $(\mathrm{H}=7.49, \mathrm{p}=0.058)$ and low PA $(\mathrm{H}=5.25, \mathrm{p}=0.154)$.

According to the questionnaire data, TABLE 5 shows significant differences in intensity of PA among groups in vigorous PA.

Fig. 1

Mean steps a day of the week in groups with different frequency of organised PA participation

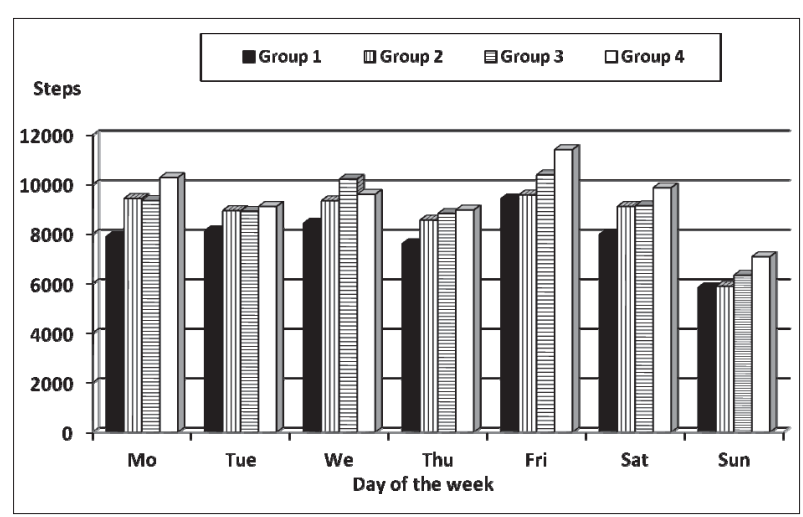




\section{Structure of weekly PA}

TABLE 6 demonstrates the differences in MET-minutes a day betweeen groups within school, transport-related, domestic and leisure-time domains. The girls with the highest participation in organised PA had the lowest value of MET-minute/day in domestic domain, but the highest value of MET-minute/day in their leisure-time.

\section{Structure of weekly PI}

The structure of PI and total sums of PI based on inactivity logs and accelerometer data are shown in TABLE 7. Regardless of the structure of PI, significantly the highest values $\left(\min \times\right.$ day $\left.^{-1}\right)$ of PI were found in the girls with the highest participation in organised PA. The significant differences in types of PI were found among groups in time spent studying and sitting at school.

\section{TABLE 4}

Intensity of PA in school days in groups with different frequency of organised PA participation (accelerometer data)

\begin{tabular}{|c|c|c|c|c|c|c|c|c|c|c|c|}
\hline \multirow{2}{*}{$\begin{array}{l}\text { Intensity of PA } \\
\left(\min \times \text { day }^{-1}\right)\end{array}$} & \multicolumn{2}{|c|}{$\begin{array}{c}\text { Group 1 } \\
(\mathrm{n}=142)\end{array}$} & \multicolumn{2}{|c|}{$\begin{array}{c}\text { Group 2 } \\
(\mathrm{n}=144)\end{array}$} & \multicolumn{2}{|c|}{$\begin{array}{c}\text { Group 3 } \\
(\mathrm{n}=113)\end{array}$} & \multicolumn{2}{|c|}{$\begin{array}{l}\text { Group } 4 \\
(\mathrm{n}=98)\end{array}$} & \multirow[t]{2}{*}{$\mathbf{H}$} & \multirow[t]{2}{*}{ p } & \multirow[t]{2}{*}{$\mathbf{n}^{2}$} \\
\hline & $M d n$ & $I Q R$ & $M d n$ & $I Q R$ & $M d n$ & $I Q R$ & $M d n$ & $I Q R$ & & & \\
\hline Vigorous & 0.43 & 2.29 & 0.93 & 2.42 & 1.85 & 4.29 & 1.79 & 4.57 & $44.56^{\mathrm{a}, \mathrm{b}, \mathrm{c}, \mathrm{d}}$ & 0.000 & $0.09 * *$ \\
\hline Moderate & 25.22 & 26.00 & 31.00 & 20.78 & 34.86 & 26.28 & 36.43 & 27.86 & $16.12 \mathrm{a}, \mathrm{c}$ & 0.000 & $0.03 *$ \\
\hline Low & 46.92 & 20.43 & 50.00 & 29.21 & 49.86 & 25.00 & 56.28 & 29.86 & $24.76 a, b$ & 0.000 & $0.05^{*}$ \\
\hline
\end{tabular}

Legend: Mdn - median values, IQR - interquartile ranges, H - Kruskal-Wallis test, p - significance level, a - significant difference between groups (4-1), b - significant difference between groups (4-2), c - significant difference between groups (3-1), d - significant difference between groups $(3-2), \mathrm{n}^{2}-* 0.01 \leq \mathrm{\eta}^{2}<0.06$ small effect size, $* * 0.06 \leq \mathrm{\eta}^{2}<0.14$ medium effect size

\section{TABLE 5}

Intensity of PA (MET-min $\times$ day $\left.^{-1}\right)$ and walk in groups with different frequency of organised PA participation (questionnaire data)

\begin{tabular}{|c|c|c|c|c|c|c|c|c|c|c|c|}
\hline \multirow{2}{*}{$\begin{array}{l}\text { Intensity of PA } \\
\left(\text { MET-min } \times \text { day }^{-1}\right)\end{array}$} & \multicolumn{2}{|c|}{$\begin{array}{c}\text { Group 1 } \\
(\mathrm{n}=142)\end{array}$} & \multicolumn{2}{|c|}{$\begin{array}{c}\text { Group 2 } \\
(n=144)\end{array}$} & \multicolumn{2}{|c|}{$\begin{array}{c}\text { Group 3 } \\
(\mathrm{n}=113)\end{array}$} & \multicolumn{2}{|c|}{$\begin{array}{l}\text { Group } 4 \\
(n=98)\end{array}$} & \multirow[t]{2}{*}{$\mathbf{H}$} & \multirow[t]{2}{*}{$\mathbf{p}$} & \multirow[t]{2}{*}{$\eta^{2}$} \\
\hline & $M d n$ & $I Q R$ & $M d n$ & $I Q R$ & $M d n$ & $I Q R$ & $M d n$ & $I Q R$ & & & \\
\hline Vigorous & 1,080 & 2,280 & 1,260 & 2,820 & 1,350 & 1,620 & 1,620 & 3,300 & $7.83^{\mathrm{a}}$ & 0.049 & $0.02^{*}$ \\
\hline Moderate & 3,763 & 4,950 & 3,144 & 4,061 & 3,240 & 3,898 & 4,371 & 5,256 & 2.73 & 0.435 & - \\
\hline Walk & 2,772 & 3,366 & 2,937 & 3,861 & 2,970 & 3,415 & 2,772 & 2,871 & 1.62 & 0.654 & - \\
\hline
\end{tabular}

Legend: Mdn - median values, IQR - interquartile ranges, $\mathrm{H}$ - Kruskal-Wallis test, $\mathrm{p}$ - significance level, $\mathrm{n}^{2}-* 0.01 \leq \mathrm{y}^{2}<0.06$ small effect size, a - significant difference between groups (4-1)

\section{TABLE 6}

Domain-related structure of PA in groups with different frequency of organised PA participation (questionnaire data)

\begin{tabular}{|c|c|c|c|c|c|c|c|c|c|c|c|}
\hline \multirow{2}{*}{$\begin{array}{l}\text { Structure of PA } \\
\left(\text { MET-min } \times \text { day }^{-1}\right)\end{array}$} & \multicolumn{2}{|c|}{$\begin{array}{c}\text { Group 1 } \\
(\mathrm{n}=142)\end{array}$} & \multicolumn{2}{|c|}{$\begin{array}{c}\text { Group 2 } \\
(\mathrm{n}=144)\end{array}$} & \multicolumn{2}{|c|}{$\begin{array}{c}\text { Group 3 } \\
(\mathrm{n}=113)\end{array}$} & \multicolumn{2}{|c|}{$\begin{array}{l}\text { Group } 4 \\
(\mathrm{n}=98)\end{array}$} & \multirow[t]{2}{*}{$\mathbf{H}$} & \multirow[t]{2}{*}{$\mathbf{p}$} & \multirow[t]{2}{*}{$\eta^{2}$} \\
\hline & $M d n$ & $I Q R$ & $M d n$ & $I Q R$ & $M d n$ & $I Q R$ & $M d n$ & $I Q R$ & & & \\
\hline School & 2,715 & 5,924 & 2,823 & 5,895 & 3,033 & 4,801 & 4,065 & 6,258 & 1.27 & 0.737 & - \\
\hline Transport & 1,188 & 1,683 & 1,386 & 2,079 & 1,314 & 1,798 & 1,037 & 1,584 & 2.55 & 0.466 & - \\
\hline Home & 1,152 & 2,160 & 1,020 & 1,620 & 765 & 1,247 & 720 & 1,270 & $14.64^{\mathrm{a}, \mathrm{c}}$ & 0.002 & 0.03 * \\
\hline Leisure & 1,391 & 2,814 & 1,815 & 3,209 & 2,102 & 2,502 & 2,930 & 4,457 & $14.18^{\mathrm{a}, \mathrm{b}}$ & 0.003 & $0.03 *$ \\
\hline Total & 9,439 & 9,070 & 7,999 & 9,493 & 8,669 & 7,465 & 9,295 & 7,841 & 1.91 & 0.592 & \\
\hline
\end{tabular}

Legend: Mdn - median values, IQR - interquartile ranges, H - Kruskal-Wallis test, $\mathrm{p}$ - significance level, $\mathrm{y}^{2}$ - $* 0.01 \leq \mathrm{y}^{2}<0.06$ small effect size, a - significant difference between groups (4-1), b - significant difference between groups (4-2), c - significant difference between groups (3-1) 
TABLE 7

Structure of PI in groups with different frequency of organised PA participation (inactivity log and accelerometer data)

\begin{tabular}{|c|c|c|c|c|c|c|c|c|c|c|c|}
\hline \multirow{2}{*}{$\begin{array}{l}\text { Type of PI } \\
\left(\min \times \mathrm{day}^{-1}\right)\end{array}$} & \multicolumn{2}{|c|}{$\begin{array}{c}\text { Group 1 } \\
(\mathrm{n}=142)\end{array}$} & \multicolumn{2}{|c|}{$\begin{array}{c}\text { Group 2 } \\
(\mathrm{n}=144)\end{array}$} & \multicolumn{2}{|c|}{$\begin{array}{l}\text { Group 3 } \\
(\mathrm{n}=113)\end{array}$} & \multicolumn{2}{|c|}{$\begin{array}{l}\text { Group } 4 \\
(\mathrm{n}=98)\end{array}$} & \multirow[t]{2}{*}{$\mathbf{H}$} & \multirow[t]{2}{*}{$\mathbf{p}$} & \multirow[t]{2}{*}{$\mathbf{n}^{2}$} \\
\hline & $M d n$ & $I Q R$ & $M d n$ & $I Q R$ & $M d n$ & $I Q R$ & $M d n$ & $I Q R$ & & & \\
\hline $\mathrm{TV}^{1}$ & 65 & 66 & 63 & 53 & 79 & 64 & 61 & 63 & 5.81 & 0.121 & - \\
\hline Computer $^{1}$ & 61 & 66 & 57 & 58 & 64 & 77 & 51 & 58 & 4.21 & 0.239 & - \\
\hline Studying ${ }^{1}$ & 64 & 77 & 58 & 64 & 69 & 71 & 86 & 89 & $9.45^{\mathrm{a}, \mathrm{b}}$ & 0.024 & $0.02 *$ \\
\hline School $^{1}$ & 139 & 83 & 159 & 54 & 156 & 60 & 169 & 50 & $25.49^{\mathrm{a}, \mathrm{b}, \mathrm{c}}$ & 0.000 & $0.05^{*}$ \\
\hline Culture $^{1}$ & 26 & 54 & 30 & 51 & 26 & 46 & 19 & 34 & 5.38 & 0.146 & - \\
\hline Passive transport $^{1}$ & 24 & 36 & 29 & 27 & 24 & 27 & 27 & 36 & 4.74 & 0.192 & - \\
\hline Total PI ${ }^{1}$ & 410 & 129 & 426 & 132 & 451 & 158 & 455 & 144 & $12.96 \mathrm{a}, \mathrm{c}$ & 0.005 & $0.03^{*}$ \\
\hline PI monitoring ${ }^{2}$ & 371 & 109 & 386 & 102 & 400 & 109 & 400 & 106 & $8.43 a$ & 0.038 & $0.02 *$ \\
\hline
\end{tabular}

Legend: Mdn - median values, IQR - interquartile ranges, H - Kruskal-Wallis test, $\mathrm{p}$ - significance level, $\mathrm{p}^{2}-{ }^{*} 0.01 \leq \mathrm{\eta}^{2}<0.06$ small effect size, a - significant difference between groups (4-1), b - significant difference between groups (4-2), c - significant difference between groups (3-1), ${ }^{1}$ - inactivity log data, ${ }^{2}$ - accelerometer-based data

\section{DISCUSSION}

In this cross-sectional study, the differences in PA and PI patterns in girls with different frequency in organised PA were investigated. The results of this study are in concordance with previous studies suggesting associations between the number of times/week the youth participate in organised PA and PA levels (Gordon-Larsen et al., 2000; Morgan et al., 2007; Mota et al., 2008; Myers et al., 1996).

The girls attending organised PA, regardless of the frequency a week, achieved more steps/day than those who did not attend the organized PA at all. The similar findings were reported in the USA by Flohr et al. (2006), where seventh-grade after-school program participants achieved $24 \%$ more steps on all days as compared to their non-participating counterparts. Similarly in the case study by Pelclová, Ansari, and Vašíčková (2010), Czech adolescent girls participating in afterschool program entered in $21 \%$ more steps/day counts than girls who did not participate. Moreover, this was true regardless of the day of the week, month and season of the year.

All participants achieved more steps on weekdays as compared to weekends, with Sunday being the least active day. This "high weekdays-low weekends" PA patterns were already examined in previous studies in adults (Tudor-Locke et al., 2004), adolescents (PeiróVelert et al., 2008; Pelclová, Ansari, \& Vašičcová, 2010) and as well as in children (Duncan et al., 2008a). This study contributes to these findings by recognizing that these patterns are similar in girls regardless of their frequency of participation in organised PA.

The more organised lessons the girls attended, the more step values they had for all days of the week. How- ever, these girls did not meet the basic recommendation of 10,000 steps/day (Hatano, 1993). Nevertheless, the organised lessons might have potential for significant increase of the number of daily steps. For instance, grade 6 and 7 pupils can add an average of 1,455 and 2,046 steps respectively in one 45-50 minute PE class (Flohr et al., 2006; Tudor-Locke et al., 2006). Due to regular participation in PE classes at school, children and youth increase their overall daily PA (Fairclough \& Stratton, 2005a; 2005b), and PA programmes in afterschool time might have greater potential for improving physical activity levels and other health-related aspects (Beets et al., 2009). For example, 104 Czech preschoolers (aged 5-7 years), 1,174 teenagers (aged 12-17 years) and 787 young adults (aged 18-24 years) had approximately three times lower activity energy expenditure during school time compared to the their after-school leisure-time periods (Sigmund, Croix, Miklánková, \& Frömel, 2007). Similarly, for both genders, the pedometer-measured steps of British children (7-11 year old) suggested that steps accumulated in weekday leisure time were greater in the high-active groups than in the mid and low active groups, with relatively smaller differences between the activity for steps accumulated at school (Hardman, Horne, \& Rowlands, 2009). Likewise in this study, significantly higher values of energy expenditure were in girls with once, twice or three or more times/week participation compared to girls without any participation in their leisure-time. However, overall self-reported energy expenditure values in all groups were the highest in school time compared to leisure time, passive transport and home time. Regarding the intensity of PA, frequency of organised PA participation was statistically positively associated mainly with vigorous PA (confirmed by both accelerometer 
and questionnaire data) in this study. However, even the girls participating 3-4 times a week did not exceed 2 min./day while performing vigorous PA. Furthermore, although the moderate to vigorous PA increased with participation in organised PA, the girls did not meet the recommended 60 minutes/week (Cavill, Biddle, \& Sallis, 2001; U. S. Department of Health and Human Services, 2008). Therefore, this study advocates the need to increase the amount of vigorous PA in any organised PA class. As organised PA programmes have the great possibility of delivering health-enhancing PA (President's Council for Physical Fitness and Sport, 2001; U. S. Department of Health and Human Services, 2008).

In addition, this study aimed to investigate the frequency of organised PA attendance and PI effect. Unexpectedly, the girls with the most frequent participation in organised PA had the highest self-reported minutes of PI spent at school or while studying. It is possible, that these girls need to compensate this with PA for rest and relaxation. Overall the girls spent on average 71 minutes watching television, 66 minutes working or playing games on computer and 31 minutes by passive transport. These findings were comparable to an American study where 15 year old girls spent 2.35 hours/day while watching TV and videos and playing games (Berkey et al., 2003). Ten and thirty minutes more than in our sample were spent by Australian girls of the same age while watching television and by passive transport respectively, and 39 minutes less while working or playing games on computer (Olds et al., 2009).

Despite the sufficient sample size, employing both self-reported and accelerometer-based data, and investigating both PA and PI, there are some limitations to the findings from this study. Since the accelerometer is not a suitable device for water activity, swimming had not been taken into consideration while processing the data. Moreover, an analysis of individual sports and activities (e.g. dance, volleyball) in relation to the participation in organised PA, analysis of PA within segmented day (e.g. PA at school and out of school), and the involvement of both genders would help to bring more a comprehensive view into this topic.

\section{CONCLUSION}

Despite the limitations discussed above, this study provides the evidence supporting the positive link between a number/week participation in organised PA and PA level. However, the findings from this study also advocate the need of increasing PA and reducing PI in girls in school or after-school periods, regardless of the participation in organised PA.
The main conclusions are:

- The positive link between a number/week participation in organised PA and PA level was confirmed using both objective and subjective research methods.

- The girls participating in organised PA 3-4 times a week had significantly higher number of steps/day, amount of moderate to vigorous PA and PA performed at school and in their leisure time than girls who did not participate at all.

- The girls with the most often participation in organised PA had the highest self-reported minutes of PI spent at school or while studying.

- The "high weekdays-low weekends" PA patterns are similar in girls regardless of their frequency of participation in organised PA.

- Regardless of the frequency of participation in organised PA, there is the need of increasing PA and reducing PI in all girls in school or after-school periods.

\section{ACKNOWLEDGEMENTS}

The study has been supported by the research grant from the Ministry of Education, Youth and Sports of the Czech Republic (No. MSM 6198959221) "Physical Activity and Inactivity of the Inhabitants of the Czech Republic in the Context of Behavioral Changes" and research grant AWF Katowice "Physical Activity and Health Lifestyle of Young”.

\section{REFERENCES}

Ainsworth, B. E. et al. (2000). Compendium of physical activities: An update of activity codes and MET intensities. Medicine and Science in Sports and Exercise, 32(9 Suppl.), 498-504.

Allison, K. R., Adlaf, E. M., Dwyer, J. J. M., Lysy, D. C., \& Irving, H. M. (2007). The decline in physical activity among adolescent students. Canadian Journal of Public Health, 98(2), 97-100.

Amstrong, N., \& Welsman, J. R. (2006). The physical activity patterns of European youth with reference to methods of assessment. Sports Medicine, 36(12), 1067-1086.

Beets, M. W., Beighle, A., Erwin, H. E., \& Huberty, J. L. (2009). After-school program impact on physical activity and fitness: A meta-analysis. American Journal of Preventive Medicine, 36(6), 527-537.

Berkey, C. S., Rockett, H. R. H., Gillman, M. W., \& Colditz, G. A. (2003). One year changes in activity and inactivity among 10 to 15 year old boys and girl: Relationship to change in body mass index. Pediatrics, 111(4), 836-843. 
Butcher, K., Sallis, J. F., Mayer, J. A., \& Woodruff, W. (2008). Correlates of physical activity guideline compliance for adolescents in $100 \mathrm{U}$. S. cities. Journal of Adolescent Health, 42(4), 360-368.

Cavill, N., Biddle, S., \& Sallis, J. F. (2001). Health enhancing physical activity for young people: Statement of the United Kingdom export consensus conference. Pediatric Exercise Science, 13(1), 12-25.

Cerin, E., Saelens, B. E., Sallis, J. F., \& Frank, L. D. (2006). Neighborhood environment walkability scale: Validity and development of a short form. Medicine and Science in Sports and Exercise, 38(9), 1682-1691.

Cohen, J. (1988). Statistical power analysis for the behavioral sciences (2nd ed.). New York, NY: Lawrence Erlbaum Associates.

Craig, C. L. et al. (2003). International physical activity questionnaire: 12 country reliability and validity. Medicine and Science in Sports and Exercises, 35(8), 1381-1395.

Duncan, E. K., Duncan, J. S., \& Schofield, G. (2008). Pedometer-determined physical activity and active transport in girls. International Journal of Behavioral Nutrition and Physical Activity, 5(2), 1-9. doi:10.1186/1479-5868-5-2.

Esliger, D. W., Copeland, J. L., Barnes, J. D., \& Tremblay, M. S. (2005). Standardizing and optimizing the use of accelerometer data for free living physical activity monitoring. Journal of Physical Activity and Health, 2(3), 366-383.

Fairclough, S. J., \& Stratton, G. (2005a). Improving health-enhancing physical activity in girls' physical education. Health Education Research, 20(4), 448-457.

Fairclough, S. J., \& Stratton, G. (2005b). "Physical education makes you fit and healthy". Physical education's contribution to young people's physical activity levels. Health Education Research, 20(1), 14-23.

Flohr, J. A., Todd, M. K., \& Tudor-Locke, C. (2006). Pedometer-assessed physical activity in young adolescents. Research Quarterly for Exercise and Sport, 77(3), 309-315.

Freedson, P. S., Melanson, E., \& Sirard, J. (1998). Calibration of the computer science and applications, inc. accelerometer. Medicine \& Science in Sports \& Exercise, 30(5), 777-781.

Frömel, K. et al. (2007). Pohybová aktivita české mládeže: koreláty intenzivní pohybové aktivity. Česká kinantropologie, 11(4), 49-55.

Gavarry, O., Giacomoni, M., Bernard, T., Seymat, M., \& Falgairette, G. (2003). Habitual physical activity in children and adolescents during school and free days. Medicine \& Science in Sports \& Exercise, 35(3), 525-531.
Gordon-Larsen, P., McMurray, R. G., \& Popkin, B. M. (2000). Determinants of adolescent physical activity and inactivity patterns. Pediatrics, 105, 83. doi: 10.1542/peds.105.6.e83.

Groffik, D., Frömel, K., \& Pelclová, J. (2008). Pedometers as a method for modification of physical activity in students. Journal of Human Kinetics, 20, 131-137.

Hardman, C. A., Horne, P. J., \& Rowlands, A. V. (2009). Children's pedometer-determined physical activity during school-time and leisure-time. Journal of Exercise Science \& Fitness, 7(2), 129-134.

Hatano, Y. (1993). Use of the pedometer for promoting daily walking exercise. ICHPER, 29, 4-8.

Jago, R., Baranowski, T., Zakeri, I., \& Harris, M. (2005). Observed environmental features and the physical activity of adolescent males. American Journal of Preventive Medicine, 29(2), 98-104.

Kahn, J. A. et al. (2008). Patterns and determinants of physical activity in U. S. adolescents. Journal of Adolescent Health, 42(4), 369-377.

Loucaides, C. A., \& Jago, R. (2008). Differences in physical activity by gender, weight status and travel mode to school in Cypriot children. Preventive Medicine, 47(1), 107-111.

Lowry, R., Galuska, D. A., Fulton, J. E., Wechsler, H., \& Kann, L. (2002). Weight management goals and practices among U. S. high school students: Associations with physical activity, diet, and smoking. Journal of Adolescent Health, 31(2), 133-144.

Morgan, C. F., Beighle, A., \& Pangrazi, R. P. (2007). What are the contributory and compensatory relationships between physical education and physical activity in children? Research Quarterly for Exercise \& Sport, 78(5), 407-412.

Mota, J., Silva, P., Aires, L., Santos, M. P., Oliveira, J., \& Ribeiro, J. C. (2008). Differences in school-day patterns of daily physical activity in girls according to level of physical activity. Journal of Physical Activity \& Health, 5(Suppl. 1), 90-97.

Myers, L., Strikmiller, P. K., Webber, L. S., \& Berenson, G. S. (1996). Physical and sedentary activity in school children grades 5-8: The Bogalusa heart study. Medicine \& Science in Sports \& Exercise, 28(7), 852-859.

Norman, G. J., Nutter, S. K., Ryan, S., Sallis, J. F., Calfas, K. J., \& Patrick, K. (2006). Community design and access to recreational facilities as correlates of adolescent physical activity and body mass index. Journal of Physical Activity and Health, 3(Suppl. 1), 118-128.

Olds, T. et al. (2009) How do school-day activity patterns differ with age and gender across adolescence? Journal of Adolescent Health, 44(1), 64-72. 
Pangrazi, R. P. (2000). Promoting physical activity for youth. Journal of Science and Medicine in Sport, 3(3), 280-286.

Park, H., \& Kim, N. (2008). Predicting factors of physical activity in adolescents: A systematic review. Asian Nursing Research, 2(2), 113-128.

Pearson, N., Atkin, A. J., Biddle, S. J. H., Gorely, T., \& Edwardson, C. (2009). Patterns of adolescent physical activity and dietary behaviours. International Journal of Behavioral Nutrition and Physical Activity, 6, 45. doi:10.1186/1479-5868-6-45.

Peiró-Velert, C., Devís-Devís, J., Beltrán-Carrillo, V. J., \& Fox, K. R. (2008). Variability of Spanish adolescents' physical activity patterns by seasonality, day of the week and demographic factors. European Journal of Sport Science, 8(3), 163-171.

Pelclová, J., Ansari, W., \& Vašíčková, J. (2010). Study of day, month and season pedometer-determined variability of physical activity of high school pupils in the Czech Republic. Journal of Sports Science and Medicine, 9, 490-498.

President's Council on Physical Fitness and Sports, U. S. Department of Health and Human Services. (2009). The president's challenge: Physical activity \& fitness awards program 2009-2010. Retrieved 20. 10. 2011 from the World Wide Web: http://www.presidentschallenge.org/misc/downloads.aspx

Sanchez, A., Norman, G. J., Sallis, J. F., Calfas, K. J., Cella, J., \& Patrick, K. (2007). Patterns and correlates of physical activity and nutrition behaviors in adolescents. American Journal of Preventive Medicine, 32(2), 124-130.

Santos, M. P., Oliveira, J., Ribeiro, J. C., \& Mota, J. (2009). Active travel to school, BMI and participation in organised and non-organised physical activity among Portuguese adolescents. Preventive Medicine, 49, 497-499.

Sheskin, D. J. (2007). Handbook of parametric and nonparametric statistical procedures. Boca Raton: Chapman \& Hall/CRC.

Sigmund, E., Croix, D. S. M., Miklánková, L., \& Frömel, K. (2007). Physical activity patterns of kindergarten children in comparison to teenagers and young adults. European Journal of Public Health, $17(6), 646-651$.

StatSoft. (2009). Statistica 9. Tulsa, OK: StatSoft.

Steinberger, J., \& Daniels, S. R. (2003). Obesity, insulin resistance, diabetes, and cardiovascular risk in children: An American Heart Association Scientific Statement from the Atherosclerosis, Hypertension, and Obesity in the Young Committee (council on cardiovascular disease in the young) and the diabetes committee (council on nutrition, physical activity, and metabolism). Circulation, 107(10), 1448-1453.
Sung, R. Y. T., Yu, C. C. W., Choi, K. C., McManus, A., Li, A. M. C., Xu, S. L.Y., Chan, D., Lo, A. F. C., Chan, J. C. N., \& Fok, T. F. (2006). Waist circumference and body mass index in Chinese children: Cutoff values for predicting cardiovascular risk factors. International Journal of Obesity, 31, 550-558. doi:10.1038/sj.ijo.0803452.

Tolson, H. (1980). An adjunct to statistical significance: $\omega^{2}$. Research quarterly for exercise and sport, 5l(3), 580-584.

Trost, S. G., \& Loprinzi, P. D. (2008). Exercise promoting healthy lifestyles in children and adolescents. Journal of Clinical Lipidology, 2(3), 162-168.

Tudor-Locke, K., Lee, S. M., Morgan, C. F., Beighle, A., \& Pangrazi, R. (2006). Children's pedometer-determined physical activity during the segmented school day. Medicine and Science in Sports and Exercises, 38(10), 1732-1738.

Tudor-Locke, C. E., Bassett, D. R., Jr., Swartz, A., Strath, S., Parr, B., Reis, J., Dubose, K., \& Ainsworth, B. E. (2004). A preliminary study of one year of pedometer self-monitoring. Annals of Behavioral Medicine, 28(3), 158-162.

U. S. Department of Health and Human Services. (2008). 2008 Physical activity guidelines for Americans. Washington, D. C.: U. S. Department of Health and Human Services.

Welk, G. J., Schaben, J. A., \& Morrow, J. R. (2004). Reliability of accelerometry-based activity monitors: A generalizability study. Medicine \& Science in Sports \& Exercise, 36(9), 1637-1645.

\section{VZTAH MEZI ORGANIZOVANOU POHYBOVOU AKTIVITOU A ÚROVNÍ POHYBOVÉ AKTIVITY A INAKTIVITY U ADOLESCENTNIICH DÍVEK}

(Souhrn anglického textu)

VÝCHODISKA: Nárůst objemu volnočasové a intenzivní pohybové aktivity, díky které je možné dosáhnout množství zdravotních benefitů a je důležitou součástí zdravého životního stylu, je u dívek možné podpořit pravidelnou účastí v organizovaných jednotkách.

CÍLE: Cílem této studie bylo analyzovat rozdíly ve struktuře a úrovni pohybové aktivity a inaktivity u dívek, které se nezúčastňuji žádné organizované pohybové aktivity, a dívek, které pravidelně navštěvují organizované jednotky.

METODIKA: Do výzkumu bylo zapojeno 497 dívek (věk 17,94 $\pm 0,52$ let) z Polska, které byly rozděleny do 4 skupin podle účasti v organizovaných jednotkách: nikdy (skupina 1), jedenkrát (skupina 2), dvakrát (skupina 3) a tři a vícekrát týdně (skupina 4). Pro posouzení úrovně a struktury pohybové aktivity a inaktivity byly 
použity tyto prostředky - polská verze mezinárodního dotazníku k pohybové aktivitě (IPAQ), akcelerometr ActiGraph GT1M a záznamy pro pohybovou aktivitu a inaktivitu.

VÝSLEDKY: Dívky, které se zúčastňovaly organizovaných jednotek tři a vícekrát týdně, dosáhly signifikantně vyššího počtu kroků/den, objemu středně zatěžující a intenzívní pohybové aktivity a pohybové aktivity ve volném čase, ale také inaktivity, než dívky, které se organizovaných jednotek nezúčastnily.

ZÁVĚRY: Pomocí této studie byl potvrzen pozitivní vztah mezi frekvencí účasti v organizovaných jednotkách $\mathrm{v}$ rámci jednoho týdne a úrovní pohybové aktivity. Zároveň však je v této studii poukázáno na potřebu nárůstu pohybové aktivity a naopak redukci pohybové inaktivity u dívek ve školních a mimoškolních podmínkách, a to i u dívek, které se již organizovaných jednotek pravidelně účastní.

Klíčová slova: denní počet kroků, středně zatěžujicí a intenzivní pohybová aktivita, akcelerometr, IPAQ, vyučovací jednotky tělesné výchovy.

\section{Prof. PhDr. Karel Frömel, DrSc.}

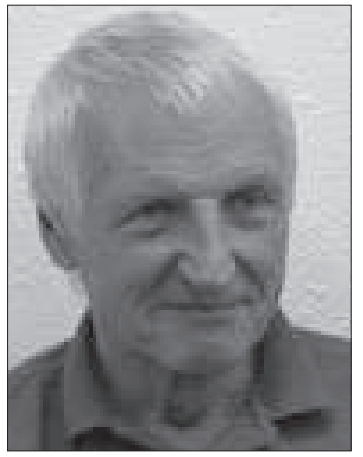

Palacký University, Olomouc

Faculty of Physical Culture

tř. Míru 115

77111 Olomouc

Czech Republic

Education and previous work experience

1976 - Palacký University in Olomouc (PhDr.).

1980 - Charles University in Prague (CSc.).

1984 - Charles University in Prague (doc.).

1992 - Charles University in Prague (DrSc.).

1997 - Palacký University in Olomouc (prof.).

\section{Scientific orientation}

Physical education, physical activity, methodology of kinanthropology.

\section{First-line publication}

Bauman, A. et al. (2009). The international prevalence study on physical activity: Results from 20 countries. International Journal of Behavioral Nutrition and Physical Activity, 6(1), 21.

Groffik, D., Sigmund, E., Frömel, K., Chmelík, F., \& Nováková-Lokvencová, P. (2012). The contribution of school breaks to the all-day physical activity of 9 and 10 year old overweight and non-overweight children. International Journal of Public Health, 57(4), 711-718.

Frömel, K., El Ansari, W., \& Vašíčková, J. (2009). The impact of teaching physical education to Czech school children using progressive teaching approaches: Findings of a four year study. Central European Journal of Public Health, 17(3), 161-168.

Frömel, K., Mitáš, J., \& Kerr, J. (2009). The associations between active lifestyle, the size of a community and SES of the adult population in the Czech Republic. Health \& Place, 15(2), 447-454.

Frömel, K., Stelzer, J., Groffik, D., \& Ernest, J. (2008). Physical activity of children ages 6-8: The beginning of school attendance. Journal of Research in Childhood Education, 23(1), 29-40. 